\title{
Navigational Aids Systems (Navaids) and Safety Measures of Aircraft : an Analysis.
}

\author{
Hassan, Adegbayi M., Akanni, C.O and Osoba, Sunday E. \\ Received: 1902 2016/ Accepted: 1006 2016/ Published online: 30122016 \\ C 2016 Faculty of Geography UGM and The Indonesian Geographers Association
}

\begin{abstract}
This study examines the availability of necessary NAVAIDS required for safe approach and landing; highlight the accidents and incidents occurrences relating to the final approach amongst others. A combination of both primary data and secondary data were employed in the study and findingsshows that there are varying degree of fluctuations in number of aircraft using NAVAIDS in Nigeria from 2003 to 2013 and that there is strong and positive correlation $(r<+0.97)$ in the relationship between the total aircraft and those that uses precision NAVAIDS for final approach and landing during that period. So also, there is strong positive correlation $(r<0.95)$ between total accidents and incidents and Approach-Landing accident and incidents between 1968 and 2012. The study recommends adequate precision approach NAVAIDS in line with International Civil Aviation Organisation (ICAO) recommendation and policy formulation on replacement of ageing and obsolete NAVAIDS in Nigerian airports among others.
\end{abstract}

Keywords: NAVAIDS, Precision, Approach, Landing, Aircraft.

\begin{abstract}
Abstrak Penelitian ini menguji ketersediaan NAVAIDS yang diperlukan untuk pendekatan dan pendaratan yang aman, khususnya pada kecelakaan dan insiden yang berkaitan dengan pendekatan akhir diantara yang lain. Kombinasi data primer dan sekunder digunakan dalam penelitian dan menunjukkan bahwa ada berbagai tingkatan fluktuasi jumlah pesawat yang menggunakan NAVAIDS di Nigeria dari tahun 2003 sampai 2013 dan menunjukkan adanya hubungan yang kuat dan positif $(r<+0,97)$ antara total pesawat dan ketelitian menggunakan NAVAIDS untuk pendekatan akhir dan pendaratan selama periode tersebut. Terdapat pula korelasi positif kuat $(r<0,95)$ antara total kecelakaan dan insiden dengan pendekatanpendaratan kecelakan dan insiden antara 1968 dan 2012. Penelitian ini merekomendasikan ketelitian menggunakan NAVAIDS untuk pendekatan sesuai dengan Organisasi Penerbangan Sipil Internasional (ICAO) dan perumusan kebijakan penggantian NAVAIDS yang usang dan tua di bandara Nigeria lainnya.
\end{abstract}

Kata kunci : NAVAIDS, Ketelitian, Pendekatan, Pendaratan, Mesin Terbang.

\section{Introduction}

Aviation industry is the main industry that links Nigeria with the outside world thereby making it possible for Nigeria to be effectively integrated with the world economy and the opportunity to benefit from the economic, technological and socio-political development around the globe, hence air transport cannot be underestimated. However, Air safety is presently being threatened more than before due to recent incessant air crashes and accidents of aircrafts in Nigeria. Within a period of six years i.e 2000 to 2006, there occurred nineteen (19) aircraft

Hassan, Adegbayi M, Akanni C.O and Osoba, Sunday E Faculty of Social and Management Sciences, Olabisi Onabanjo University, Ago-Iwoye.

simplygbayi@gmail.com a space of one year Aviation Safety Network/ASN [Aviation Safety Database, 2007]. Air crashes and incidents do occur at any stage of air navigation, but it is generally known in aviation industry that taking-off and landing of aircraft are the most critical stages, for instance, the Sosoliso Airline 5NBFD Accident of $10^{\text {th }}$ December, 2005 occurred in the final phase of landing in Port-Harcourt, Nigeria with 108 fatalities Aviation Safety Network/ASN [Aviation Safety Database, 2007]. Furthermore, out of the nineteen (19) aircraft accidents/incidents in Nigeria from 2000 to 2006 earlier mentioned eleven (11) occurred during the final phase of approach and landing Aviation Safety Network/ASN [Aviation Safety Database, 2007]. At the final phase, aircraft are expected to be fully established on NAVAIDS Approach i.e on instrument approach, making use of Instrument Landing System 
Navigational Aids to enhance safety and ensure safe landing.

Demuren [2006] pointed out that safety is the major pivot on which aviation activities revolve while Adesanya [2001] viewed accident occurrences in Nigeria as a major source of concern to air passengers. Air transport services are designed to meet the needs and tastes of customers which are not met until a passenger's journey or freight arrived safely. The concept of safe arrival according to Steward [1980] is not confined to merely avoidance of injury or damage but that passengers are not to be exhausted by sickness, fear, discomfort or frustration. In air transportation, safety of lives and properties is the utmost priority of aviation industry, in this regard, the International Civil Aviation Organisation (ICAO) have set a very high standards to be met by all operators in the industry, to ensure that high safety level is obtained. So also, the System concept according to Shaw [1993] emphasizes that obstruction in any part of the system affects its entirety, in other words, each sub-system is an integral part of the main system, functioning together for a desired output. Specific factors involved in air accidents occurrence have been grouped together through the process of their individual interaction as a system with a background understanding that a mistake or fault committed in either of the system interacting together is capable of giving an output called accident i.e. any malfunction of any of the subsystem affects the whole system of flight safety.

However, Bello [1996] linked some causes of air accidents especially in developing countries to technological restrictions and economic constraints, attributing air crashes and accidents to crews failure in several ways which include unstabilized approach to runway, uncontrolled flight into terrain and noncompliance with stated regulations among others. Slater (1998) opined that accident, age of aircraft, mechanical error, weather, maintenance, pilot error and air traffic control procedures are major factors for accident occurrence. In his study of the safety and security of Nigerian Airspace, Agboola [2001] emphasize that communication system should be improved upon as safety of airspace requires much exchange of data on flights to ascertain authorized flights from non-authorized flights. Sene [2004] pointed out that the safety of any flight is largely dependent on the security at the airport during takeoff or landing and stressed that a safe, efficient and regular air navigation system must be developed to the same status in order that air traffic load does not exceed either the airport or air navigation capacity. The main aim of this study is to contribute to literature on the role of Navigational Aids Systems (NAVAIDS) on the safety of aircraft in the final approach and landing using Murtala Muhammed International Airport, Ikeja as a case study. The objectives that guided the study include the examination of availability of necessary NAVAIDS required for safe approach and landing; highlighting the accidents and incidents occurrences relating to the final approach and landing stage phase and examination of the safety measures of NAVAIDS to the aircraft in the approach and landing stage.

\section{The Methods}

Both primary and secondary data were obtained and used in the course of this study. Information relating to primary data includes administration of questionnaires requesting for information from respondents who are professionals in aviation industry mainly Pilots, Flights/Aircraft Engineers, Air Traffic Controllers, Aviation Safety Inspectors, Meteorologists and Aero-nautical Communicators as shown in Table 1. Personal interviews of key professionals in the industry also formed part of the primary data. Stratified Sampling - a probability sampling technique was applied in the administration of questionnaire. Relevant secondary data for this study were the data on aircraft reliance on NAVAIDS relating to safety issues on air accidents and incidents on the final approach phase which was obtained from the records of relevant agencies in aviation industry. Records on availability of NAVAIDS for approach and landing were obtained from Nigerian Airspace Management Agency (NAMA), in addition, records of past aviation accidents were also obtained from Nigerian Civil Aviation Agency (NCAA).

Data collected were analyzed using descriptive statistics such as frequency distribution and percentages while inferential statistics such as Pearson Product Moment Correlation was used to find out the degree of relationship between the total aircraft accidents and those accidents that occurred during the final approach-landing stage. It is also 
used to find out the nature and degree of relationship between the total arrivals and those arrivals that use the precision NAVAIDS in landing. The correlation coefficient determines the nature and degree of reliance on precision NAVAIDS by aircraft and by extension the procedure that enhances safety.

Table 1. Targeted Population of Professional Groups.

\begin{tabular}{|c|c|c|c|}
\hline Professional Groups & $\begin{array}{l}\text { Target Population } \\
\text { (MMIA Ikeja) }\end{array}$ & $\begin{array}{l}{ }^{\star} \text { Quota sample (20\% } \\
\text { of Total Population }\end{array}$ & Data Source \\
\hline Pilots & 227 & 44 & $\begin{array}{l}\text { NCAA, Directorate of Airwothiness and } \\
\text { Standards.MMIA }\end{array}$ \\
\hline $\begin{array}{l}\text { Flight/Aircraft } \\
\text { Engineers }\end{array}$ & 75 & 16 & $\begin{array}{l}\text { NCAA, Directorate of Airwothiness and } \\
\text { Standards.MMIA }\end{array}$ \\
\hline $\begin{array}{l}\text { Air Traffic Safety } \\
\text { Engineers }\end{array}$ & 83 & 16 & $\begin{array}{l}\text { NAMA, Directorate of ATSES- Training } \\
\text { and Staff Matters Department MMIA, } \\
\text { Ikeja }\end{array}$ \\
\hline Air Traffic Controller & 88 & 18 & $\begin{array}{l}\text { NAMA: Directorate of ATS-ATC } \\
\text { Technical Evaluation } \\
\begin{array}{l}\text { MMIA, Ikeja }\end{array}\end{array}$ \\
\hline $\begin{array}{l}\text { Aviation } \quad \text { Safety } \\
\text { Inspectors }\end{array}$ & 48 & 10 & $\begin{array}{l}\text { NCAA: Directorate of Airwothiness and } \\
\text { Standards.MMIA }\end{array}$ \\
\hline Meteorologists & 38 & 8 & NIMET: MMIA, Ikeja \\
\hline $\begin{array}{l}\text { Aero-Nautical } \\
\text { Communicators }\end{array}$ & 43 & 8 & $\begin{array}{l}\text { Directorate of AIS, Aero-Nautical } \\
\text { Communication Department NAMA } \\
\text { headquarter }\end{array}$ \\
\hline Total & 602 & 120 & \\
\hline
\end{tabular}

Source : Field Survey [2014]

The quota sample of $20 \%$ of the target population is considered to be accessible population, considering the nature of the respondents.Murtala Muhammed International Airport Ikeja is located in Lagos which is referred to as the economic hub of Nigeria and has about $7.5 \%$ of the total population of Nigeria [National Population Commission Census, 2006]. The airport has an international terminal, a cargo terminal as well as two domestic terminals. A new domestic terminal named MurtalaMuhammed Airport (MMA2) was opened for traffic and air transport activities on April 7, 2007. Also the airport is served by two physical runways: The international terminal is served by $3900 \mathrm{~m}$ length $60 \mathrm{~m}$ width runway while the domestic terminal runway is $2743 \mathrm{~m}$ long and $45 \mathrm{~m}$ wide, both are asphalt concrete surfaced. Apart from the runways which was designed for critical aircraft of B747 and Concord types, other NAVAIDS facilities for air navigation and safety include two ILS CAT2, VOR, DME, Terminal RADAR, TRACON, Visual Approach Guidance (VAG). Murtala Muhammed
International Airport Ikeja is a federal government owned airport which is designated by International Air Transport Association (IATA) as LOS and International Civil Aviation Organisation (ICAO) as DNMM, having its central geographical coordinate for locating the airport at $06^{\circ} 34^{\prime} 29^{\prime \prime} \mathrm{N}$, $03^{0} 19^{\prime} 07^{\prime \prime} \mathrm{E}$. The airport is the first and the busiest in terms of passenger, aircraft and cargo movement of the four major international airports in Nigeria

\section{Result and Discussion}

Table 2 shows the yearly aircraft arrivals into MMIA using different approaches from 2003 to 2013. It also shows the yearly total aircraft landings that specifically made use of precision NAVAIDS systems for the same period. The percentage of the total aircraft arrivals that made use of precision NAVAIDS systems for 2003 was $96.5 \%$ with a slight increase of $0.4 \%$ in 2004 . Though the total aircraft arrivals increased by $10.8 \%$ in 2005 but there was a $2.2 \%$ decrease in the total arrivals that made use of precision NAVAIDS systems. The downward trend continues in 2006 
with only $92.1 \%$ arrivals using the precision NAVAIDS, resulting in a decrease of $2.6 \%$ over that of 2005. The year 2007 witnessed an increase in total arrivals of $11.8 \%$ over that of 2006 with an increase of $2.7 \%$ with the usage of precision NAVAIDS system. There has been an increment in total aircraft landings that specifically made use of precision NAVAIDS systems from 2008 to 2011 i.e
$68.9 \%, \quad 74.1 \%, \quad 83.8 \%$ and $97.9 \%$ respectively; however, there was a drop in 2012 and 2013 with a downward trend of $96.5 \%$ and $94.3 \%$ respectively. However, the relationship between the total aircraft arrivals and those that use precision NAVAIDS for final approach and landings shows an indication of strong and positive correlation at +0.97 .

Table 2. Aircraft Arrivals at Murtala Muhammed International Airport, Ikeja from 2003 to 2013.

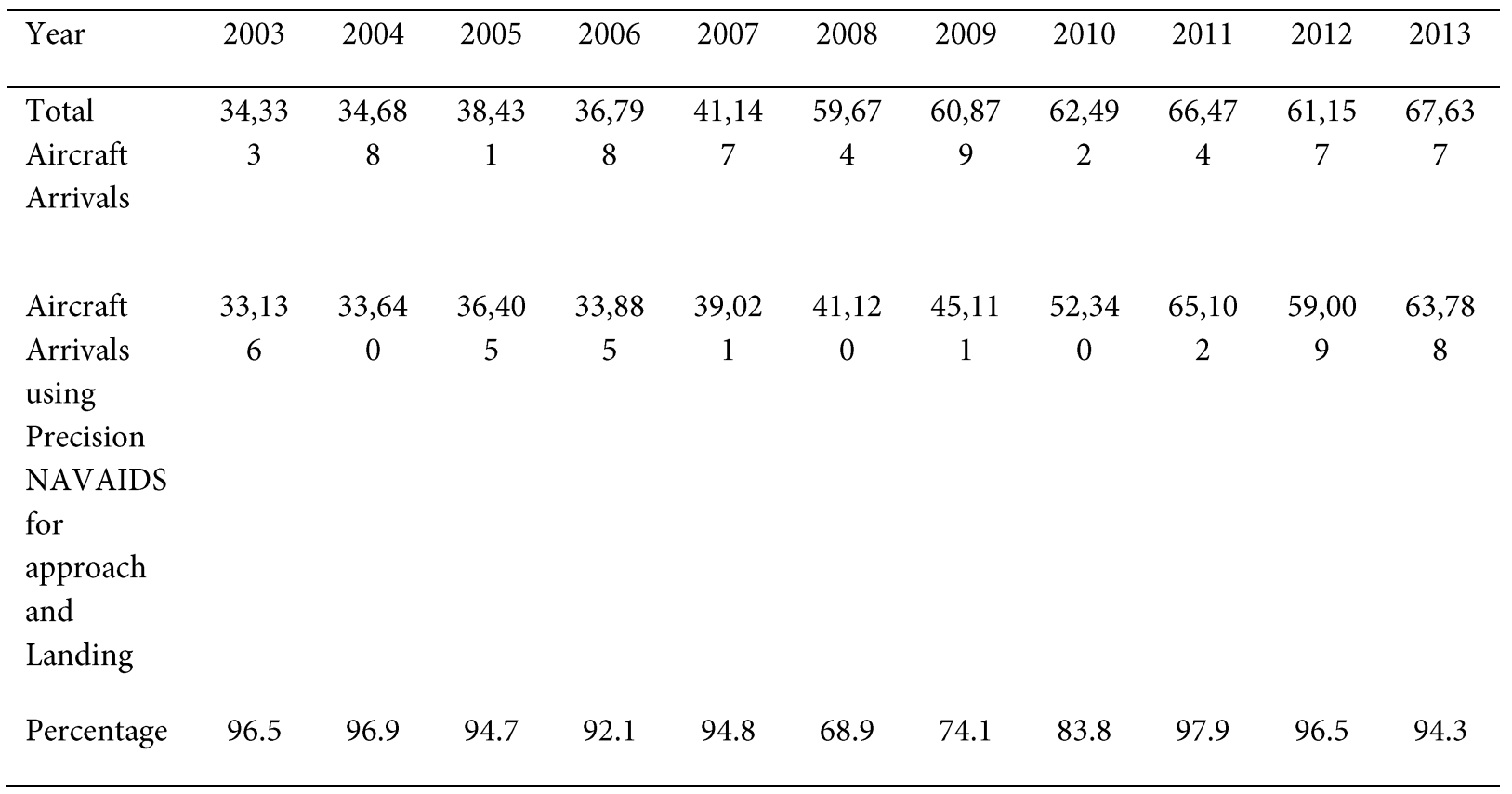

Source : Aviation Safety Network Database [2014]

Table 3 shows the 11-year period of aircraft accident and incidence at MurtalaMuhammed International Airport, Ikeja, between 1968 to 2012. The approach -landing phase accidents and incidents at MMIA indicated that between 1968-1972, 87.5\% of the accidents occurred during the approach-landing stage while all the accidents/Incidents that occurred in the 10 year period of 1973 to 1982 were all Approach and Landing Accidents. Also for the 10 year period of that followed, there was a significant reduction of 50\% when compared with the Approach Landing Accidents preceding years. However, from 1993 to 1997 the Approach Landing Accidents increased to $75 \%$ of the total accidents and incidents and dropped to $60 \%$ in the 5 -year period that followed and finally increased to $80 \%$ in 2003 to 2007 . So also in the 5-year period between 2008 to 2012 there was an increase in aircraft accidents by $50 \%$. The strength or degree of relationship between the total accidents and incidents and the ApproachLanding phase accidents and incidents was found to be +0.95 which shows a positive correlation. Invariably, this shows that air accidents can still occur despite NAVAIDS precision system.

The perceptual view of respondents as depicted in Table 4, shows that $93.1 \%$ of respondents agreed that precision approach is the most appropriate when high safety is considered on the final phase of approach and landing on the runway. Only $6 \%$ and $0.9 \%$ agreed that Nonprecision approach and visual approach is the most appropriate respectively. So also, $41.4 \%$ of the total respondents strongly agreed that Pilots should be on NAVAIDS instruments approach rather than visual approach, $46.5 \%$ agreed, $10.3 \%$ were indifferent to the approach used by Pilot, those that disagreed and strongly disagreed were $0.9 \%$ and $0.9 \%$ respectively. In addition, all the respondents opined that available precision landing system in 
Navigational Aids enhances safe approach and landing on runway. Finally, opinion of respondents on the rating of the provision of Navigational aids in MMIA shows that $6.9 \%$ agreed that it is very adequate, $46.6 \%$ opined that it is adequate, $36.2 \%$ viewed it as being on the average, $7.7 \%$ agreed that it is inadequate while $2.6 \%$ agreed that it is grossly inadequate.

Table 3. Aircraft Accidents and Incidents at MurtalaMuhammed International Airport, Ikeja. 1968-2012.

\begin{tabular}{cccc}
\hline Year & $\begin{array}{c}\text { Total Accidents and } \\
\text { Incidents }\end{array}$ & $\begin{array}{c}\text { Approach/Landing Phase of Accidents } \\
\text { and Incidents }\end{array}$ & $\begin{array}{c}\text { Percentage Difference } \\
1968-1972\end{array}$ \\
\hline $1973-1977$ & 2 & 7 & 87.5 \\
$1978-1982$ & 2 & 2 & 100 \\
$1983-1987$ & 2 & 2 & 100 \\
$1988-1992$ & 4 & 1 & 50 \\
$1993-1997$ & 8 & 2 & 50 \\
$1998-2002$ & 5 & 6 & 75 \\
$2003-2007$ & 5 & 3 & 60 \\
$2008-2012$ & 4 & 4 & 80 \\
\hline
\end{tabular}

Source : Aviation Safety Network Database [2014]

Table 4. Perceptual View of Respondents' about NAVAIDS on Approach and Landing

\begin{tabular}{lcc}
\hline \multicolumn{1}{c}{ Variables } & Frequency & Percentage \\
\hline (1) Approach Consider most Appropriate on final phase of Approach and Landing & & \\
(a) Precision Approach & 108 & 93.1 \\
(b) Non-Precision Approach & 7 & 6.0 \\
(c) Visual Approach & 1 & 0.9 \\
(2) Preference of NAVAIDS instrument Approach over Visual Approach & & \\
(a) Strongly Agree & 48 & 41.4 \\
(b) Agree & 54 & 46.5 \\
(c) Indifferent & 12 & 10.3 \\
(d) Disagree & 1 & 0.9 \\
(e) Strongly Disagree & 1 & 0.9 \\
(3) Availability of Precision Landing NAVAIDS in Approach and Landing on & & \\
Runway enhances safe approach & & \\
(a) Available & 116 & 100 \\
(b) Not Available & 0 & 0 \\
(c) Indifferent & 0 & 0 \\
(4) Rating of the provision of Navigational Aids Landing System in MMIA & & \\
(a) Very Adequate & 8 & 6.9 \\
(b) Adequate & 54 & 46.6 \\
(c) Average & 42 & 36.2 \\
(d) Inadequate & 9 & 7.7 \\
(e) Grossly Inadequate & 3 & 2.6 \\
\hline Solf A & & \\
\hline
\end{tabular}

Source : Author's Field Survey [2014] 


\section{Conclusion}

Other phases of air navigation are also important as regards safety, but this study has revealed that more emphasis should be placed on the final approach-landing phase as regards safety of aircraft. So also, Accidents and incidents are results of inadequate measures of safety degradation and one of the main measures of safety is the provision of adequate precision approach NAVAIDS systems during final approach and landing. The study however recommended that

\section{References}

Adesanya, A. (2001). Analysis and Management of Transport and Aviation Sector Performance and its Inter-Sectoral Linkages. Paper Presented at the Training Programme on Sectoral Policy Analysis and Management. National Centre for Economic Management and Advancement, NCEMA. Ibadan

Agboola, N. O (2001). Appraisal of Safety and Security of Nigerian Airspace in the 1990s. Unpublished M.Sc. Dissertation in the Centre for Transport Studies, Olabisi Onabanjo University. Ago-Iwoye. Nigeria

Aviation Safety Network (2007a). ASN Aviation Safety Database. Publication of Flight Safety Foundation March Edition.

Aviation Safety Network (2007b). Lagos-Murtala Muhammed Airport Profile. Publication of Flight Safety Foundation. March Edition.

Bello, F. A (1996). Air Crash Analysis: Nigeria Transport. Magazine of the Chartered Institute of Transport and Logistics. $7^{\text {th }}$ Edition, March, Page 31.

Demuren, H.O. (2006). Routine Incidents Accidents airport authorities should provide adequate precision approach NAVAIDS in line with International Civil Aviation Organisation (ICAO) recommendation and international standards. The NAVAIDS should be well maintained, operational and serviceable; available for aircraft usage to enhance safety. There should be policy formulation and implementation on replacement of ageing and obsolete NAVAIDS in Nigerian airports, training of personnel to handle these instruments is also very important.

\section{in the Aviation Industry Crisis Communication. A paper presented at league of Airport and Aviation Correspondence Retreat at Otta, Ogun State. $19^{\text {th }}$ May $-20^{\text {th }}$ May.}

Filani, M. O (1986). Air Transport Development and Traffic Trends in Falola $T$ and Olanrewaju S.A (eds). "Transport System in Nigeria" Maxwell School of Citizenship and Public Affairs, Syracuse University, New York. PP 93-105

Hassan, A.M (2007). The Spatio-Temporal Dynamics of Air Traffic Flow in Nigeria: Angy analysis. An Unpublished M.Sc. Dissertation in the Centre for Transport Studies, Olabisi Onabanjo University, Ago-Iwoye, Nigeria.

Sene, A. (2004). Flight Safety and GNSS. A paper presented at ATN/GNSS Seminar, Nairobi, Kenya. $28^{\text {th }}$ Sept- $1^{\text {st }}$ Oct. 2004

Steward, D. (1980). The Theory and Practice of Transport. Heinemann Book Publisher, London.

Shaw, S.J. (1993). Transport: Strategy and Policy. Blackwall Business Oxford. UK. 